\title{
A Witness Tree Analysis of the Effects of Native American Indians on the Pre-European Settlement Forests in East-Central Alabama
}

\author{
H. Thomas Foster II, ${ }^{1,3}$ Bryan Black, $^{2}$ and Marc D. Abrams ${ }^{2}$
}

Witness tree data from the southeastern United States (lat $33^{\circ} 30^{\prime} \mathrm{N}$, long $\left.86^{\circ} 30^{\prime} \mathrm{W}\right)$ were analyzed using catchment and distance analysis to quantify the effects of Native American settlement on the composition offorest trees. Thirty Creek Indian villages comprising 18 settlement catchments were included in the sample, which is the largest Native American-forest interaction study using witness trees to date. Lower frequencies of Pinus spp. were observed within village catchments of the Coastal Plain and Ridge and Valley. Elevated frequencies of early succession species were observed surrounding $2 \mathrm{~km}$ village catchments. Distance analysis at two relatively isolated towns showed that Pinus increases in frequency beyond $2000 \mathrm{~m}$ from villages while Carya had the opposite result. Field and fruit species were more frequent within $6000 \mathrm{~m}$ of villages and then dropped off in frequency. Fire-sensitive tree species appear to be in a spatially cyclical pattern.

KEY WORDS: Native American; forest composition; witness tree; human-forest interaction; Alabama.

\section{INTRODUCTION}

Researchers of pre-European settlement forest distributions have long recognized the impacts Native Americans have had on forest structure and composition (Bartram, 1998; Day, 1953; Delcourt, 1976; Delcourt and

\footnotetext{
${ }^{1}$ Panamerican Consultants, Inc., 4711 Milgen Road, Columbus, Georgia 31907.

${ }^{2}$ School of Forest Resources, Ferguson Building, The Pennsylvania State University, University Park, Pennsylvania 16802.

${ }^{3}$ To whom correspondence should be addressed; e-mail: tfoster@panamconsultants.com.
} 
Delcourt, 1974; Ruffner, 1999; Wykoff, 1991). Early historic American explorers and settlers observed Native Americans performing activities that could have affected the distribution and frequency of forest tree species (Adair, 1930; Bartram, 1998; Day, 1953; Lafitau, 1724; Milfort, 1972; Sagard, 1968). Such activities include Native Americans clearing the forests for village construction, cutting fuelwood, clearing agricultural plots, starting forest fires, and favoring species that served as food sources. In earlier research, evidence as to the impacts of these activities on pre-European settlement forests was strictly qualitative, including narratives by early travelers and settlers (Day, 1953). More recent investigations have taken quantitative approaches using a variety of historical sources (Delcourt, 1976; Delcourt and Delcourt, 1974; Wycoff, 1991).

One widely used technique is the stratigraphic analysis of bog or lake sediments in which forest composition and disturbance regimes are constructed from pollen counts and charcoal fragments. These pollen studies can generate composition histories several thousand years long but are localized to the region immediately surrounding the sample locus and have a low resolution. For example Clark and Royall (1995) showed compositional changes in Ontario. Similarly, Delcourt et al. (1998) showed that in present day Kentucky, northern white cedar were replaced by mixed mesophytic species after the early Holocene, 7300 B.P. After 3000 B.P., mixed oak-chestnut and pine forests were dominant and there was a major increase in large charcoal particles. Pollen analysis suggests that Late Archaic and Woodland peoples (ca. 3000-1000 B.P.) cleared forest gaps to cultivate native plants and that anthropogenic fires served to increase populations of oak, chestnut, and pine in the uplands (Delcourt et al., 1998).

Another source of quantitative data on the pre-European settlement forests is witness trees recorded in original land survey notes and maps. When land was sectioned for government distribution, two to four makers were identified at each half-mile interval. These markers could be posts or stones, but most often were trees. These trees were recorded on field notes and sometimes maps and provide an unintentional, systematic, and largescale sample of the forest at the time of the land survey.

Witness (bearing) trees have become a widely used method of characterizing pre-European settlement forest vegetation in regions where most or all of the forests have been cut down as a consequence of European agricultural and timbering methods (Abrams and Ruffner, 1995; Black and Abrams, 2001; Bourdo, 1956; Early, 2000; Lutz, 1930; Milner, 1998; Sabo et al., 2002; Schroeder, 1997). Although witness tree data may contain certain biases, such as surveyor bias, fraud, and selective recording (Bourdou, 1956), they have been addressed for the dataset used in this study as described in detail 
in Black et al. (in press). These witness tree data provide the best-known method for describing the forest before European settlement and during Native American settlement.

Although witness trees provide an easily collected and well-studied method for characterizing the pre-European settlement forests, this type of analysis has only recently been applied to the issue of Native American influences on the forest distribution (Black and Abrams, 2001; Delcourt, 1976; Delcourt et al., 1998; Dorney, 1981; Dorney and Dorney, 1989; Early, 2000; Milner, 1998; Ruffner, 1999; Sabo et al., 2002; Schroeder, 1997). This witness tree approach has been successful at quantitatively characterizing largescale changes in tree frequencies. Black and Abrams (2001) and Ruffner (1999) used witness trees and site catchment analysis to identify the effects of Native American cultural behavior on pre-European forest distribution. Ruffner (1999) found a higher frequency of oak-hickory-chestnut trees surrounding Iroquois Indian villages. Black and Abrams (2001) found elevated frequencies of hickory, walnut, and locust near Native American villages of southeastern Pennsylvania.

Most studies of Native American forest alteration cite historic anecdotal references to Native Americans using fire or using trees for subsistence but do not quantify or characterize the effects of the Native American behaviors on specific tree species. Native American use of forest fires in subsistence activities is cited most often (Clark and Royall, 1995; Davies, 1994; Delcourt, 1976; Delcourt et al., 1998; Dorney, 1981; Dorney and Dorney, 1989; Kusmer et al., 1987; Munson, 1986; Pyne, 1983).

The ability to accurately characterize Native American occupation and resource use in the past is extremely important to Native American forest studies, particularly witness tree studies, because humans have been living in North America for at least 12,000 years. Native American occupation has varied significantly over that time frame and over space, however. There is probably no area in North America that has never been influenced by humans since Native Americans first inhabited the continent. Consequently, it is necessary to perform these Native American forest effect analyses in regions where the Native American occupation, particularly the recent historic occupation, is very well known.

This paper describes witness tree research in Alabama that includes a sample much larger than any other Native American-forest interaction study. Consequently, we are able to better characterize the various effects of Native Americans on the distribution of forest trees. We use catchment analysis on a sample of 30 Creek Indian towns combined into 18 catchments and then use distance analysis on 2 of those towns in order to quantify the degree of influence that Indian settlement had on specific trees. The Creek 
Indians were settled into what is now central Georgia and Alabama during the seventeenth to the early nineteenth century when they were forcibly removed by the U.S. government from that location. These Indians were chosen for our study because they have been well studied (Ethridge, 1996; Foster, 2001; Waselkov and Smith, 2000; Worth, 2000). Their population movement and occupation are well known and there is a large sample of villages. In addition, the villages were occupied until the time of the land surveys and should contain evidence of the effects of Indians on the forest composition. Our findings are relevant to environmental management, human ecology, anthropology, forestry, and restoration ecologists.

\section{STUDY AREA}

The study region (Fig. 1) in east-central Alabama (lat $33^{\circ} 30^{\prime} \mathrm{N}$, long W $86^{\circ} 30^{\prime}$ W) encompasses 686,569 ha of the Coastal Plain, 741,191 ha of the Piedmont, and 191,553 ha of the Ridge and Valley physiographic provinces (Fig. 1; Fenneman, 1938). Elevations on the Coastal Plain range from 40 to approximately $200 \mathrm{~m}$ asl. The Piedmont region has two major physiographic sections: the Opelika Plateau and the Ashland Plateau. Elevations in the Opelika Plateau range from 60 to $270 \mathrm{~m}$ asl and topography is gently rolling. Soils in this district are moderately deep with a loamy surface. The Ashland Plateau is more mountainous and dissected by numerous ridges with elevations between 40 and $360 \mathrm{~m}$ asl. A small portion of the study region is within the Coosa Valley district of the Ridge and Valley physiographic region. Elevations range from about $100 \mathrm{~m}$ at the valley floors to about $540 \mathrm{~m}$ on the ridges.

The climate in this region is almost subtropical. Temperatures range from an average of $10^{\circ} \mathrm{C}$ in the winter to $32^{\circ} \mathrm{C}$ in the summer. Average precipitation is about $137 \mathrm{~cm}$. The average growing season is about 250 days with March 8 being the average last day of frost and November 13 being the average first day of frost (Burgess et al., 1960).

Two major forest types occur in the forest region today, the Oak-Pine and the Southeastern Evergreen Region (Braun, 1950; Waggoner, 1975). The Oak-Pine region is dominated by oaks, but pines, especially loblolly pine (Pinus taeda L.), are dominant in areas of poorer soils. The Southeastern Evergreen Region is dominated by broad-leaf evergreens and coniferous species, particularly longleaf pine (Pinus palustris Mill.; Braun, 1950).

The pre-European settlement forest of the study region has recently been analyzed using witness trees (Black et al., in press) and will not be described in detail here. The pre-European settlement forest was dominated by three communities: pine-blackjack-oak, oak-hickory, and white 


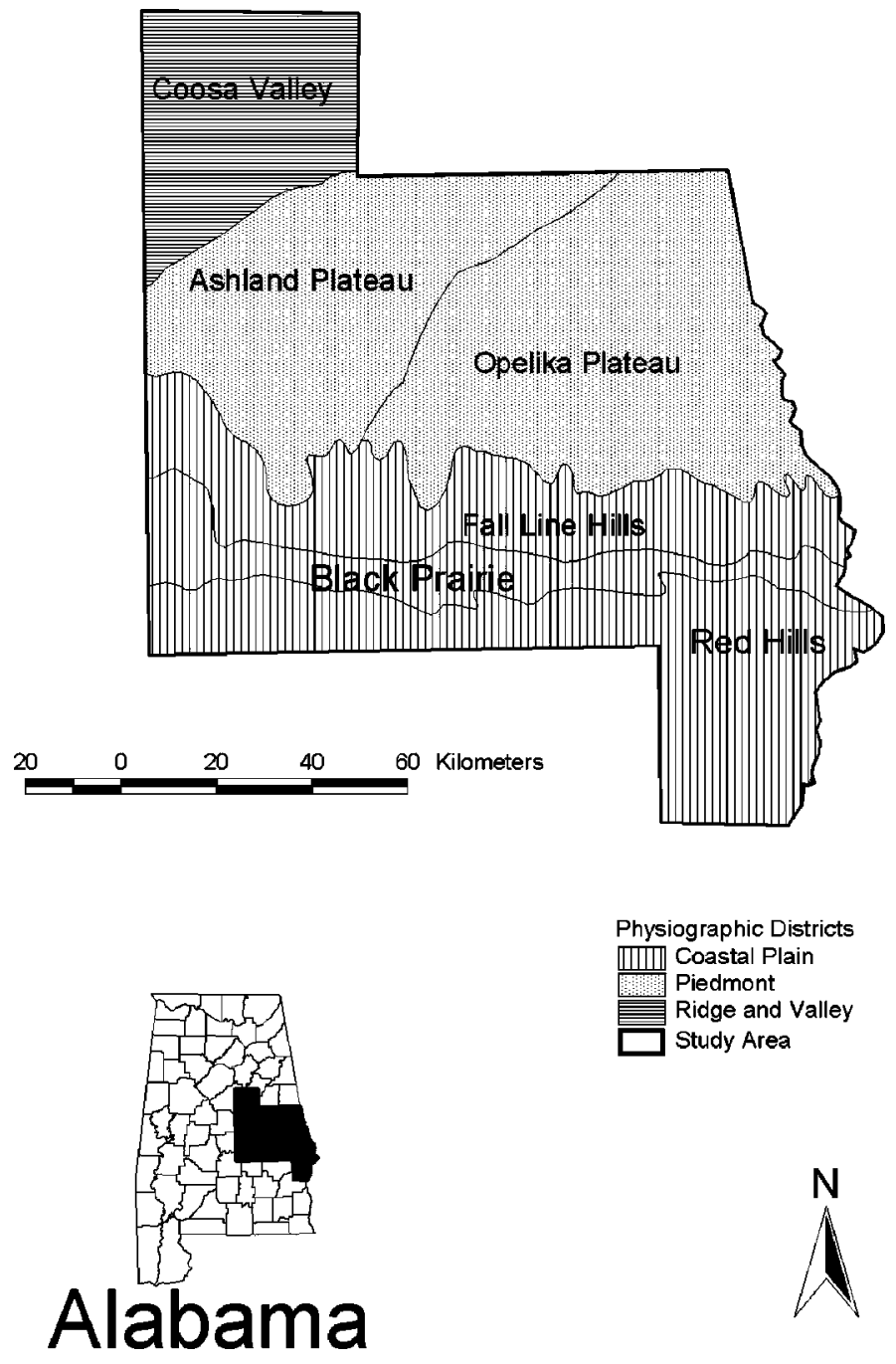

Fig. 1. Map of study area in east-central Alabama.

oak-mixed mesophytic. Pine-blackjack-oak dominated the ridges of the Ridge and Valley, and the uplands of the coastal plain. Oak-hickory was dominant on the piedmont and valley floors of the Ridge and Valley. Species characteristic of this community included southern red oak ( $Q$. falcata Michx.), post oak (Q. stellata Wangenh.), black oak ( $Q$. velutina Lam.), hickory (Carya), and American chestnut (Castanea dentata (Marsh.) Borkh.). 
Finally, white oak-mixed mesophytic forests occurred in stream valleys and flood plains throughout the study area. Dominant species included white oak (Q. alba L.), beech (Fagus grandifolia Ehrh.), bass wood (Tilia Americana L.), birch (Betulaceae), tulip tree (Liriodendron tulipifera L.), and red maple (Acer rubrum L.; Black et al., in press).

Native American Indians occupied the study region for thousands of years before European settlement. The most recent and intensive preEuropean occupation was by the Creek Indians. The Creek Indians were an amalgam of linguistically diverse populations that settled into the central and eastern Alabama region in various stages of migration from about A.D. 1500 to 1800 . These Indians were politically organized into tribes consisting of a town and its associated satellite villages. Populations in the Creek Indian towns averaged between a few hundred to about a thousand individuals during the seventeenth to nineteenth centuries. The total Creek Indian population varied over time but was counted at 21,733 by the federal government in 1832 when the Indians were forced to move to reservations in what is now Oklahoma (Swanton, 1922).

Creek Indian towns and villages were situated immediately adjacent to the rivers for access to water, transportation, and fertile agricultural land. The Creek Indians were horticulturalists subsisting mostly on maize, beans, and squash, supplemented by hunting and gathering. Their agricultural fields averaged about 100 acres ( $33 \mathrm{ha}$ ) depending on the size of the town. The fields were usually immediately adjacent to their towns and were situated on the rich river bottom alluvial soils. Fields were cleared through a mix of girdling large trees and burning the undergrowth. Because of their technology, Native Americans rarely cut down large virgin forests (Silver, 1990; Waselkov and Braund, 1995). Fire was also used for hunting, particularly in the fall and winter, by encircling deer to drive them in a particular direction (Swanton, 1979, 318).

\section{METHODS}

Methods for collecting witness tree data are described in detail elsewhere (Black et al., in press). In the study area, the land surveys were collected during the 1820 s through the 1840 s and the Creek Indians were removed from the study area between 1825 and 1836. Therefore, the witness tree record is likely to capture the Native American influences on forest composition.

The land survey documents from the study region have been microfilmed and were obtained from the United States Bureau of Land Management. Witness trees were extracted from the microfilm and then digitized 
onto the Public Land Survey System digital line graphs (DLG) from the United States Geological Survey (USGS) using Arcview 3.2a and Arc/Info 8.02 (ESRI, Redlands, California). Trees are listed by common name in the survey notes. These common names were translated to species from Godfrey (1988).

After the witness trees were tabulated, we used catchment analysis to investigate Native American-forest interaction in this study (Black and Abrams, 2001; Ruffner, 1999; Vita-Finzi and Higgs, 1970). Catchment analysis identifies regions of "use areas" around residential sites (Vita-Finzi and Higgs, 1970). Catchments are artificially defined regions and are intended as a measure of behavioral influence on a geographic area. For example, a catchment around a Native American town represents the region that the inhabitants of the town used. In a witness tree application of Native American-forest interaction, a catchment is defined around the location of a known Indian town, and the witness trees within that area serve as a sample and measure of "Native American effects on the forest." This catchment sample can be compared to another catchment of similar size elsewhere. By randomly placing catchments in non-Native American settlement regions, we can compare the effects of Native American cultural behaviors around their towns to a control sample of catchments. Previous applications of witness tree catchment analysis to Native American-forest effects have been limited to small catchment sample sizes. Black and Abrams (2001) and Ruffner (1999) both used only three catchments. The analysis in the present paper improves on these previous studies by applying the technique to a much larger witness tree catchment sample and to a region where Native American settlement is known in greater detail. Consequently, this study can better characterize the regional effects that Native Americans had on tree distributions. For analytical comparability, the catchments are usually circles of a standard distance from the point of interest. Two-kilometer catchments were used in this study because, as demonstrated elsewhere (Ethridge, 1997; Foster, 2001; Waselkov, 1997), regions of this size encompass agricultural fields, towns, and resource collection areas for the Creek Indians. In our study area, a 2-km catchment includes approximately 48 witness trees. Thirty Creek towns were chosen because of knowledge of their occupation history and population size. Some towns were so close to neighboring towns that they were combined in a single settlement catchment to form a total of 18 settlement region catchments (Table I).

Control catchments were created by identifying catchments of similar size in areas immediately adjacent to the experimental catchments, located on sites with comparable soil parent material, distance to water, topography, physiographic region, and forest type. We analyzed our data within each physiographic region because forest composition is variable among 
Table I. Creek Towns Used in Catchment Study

\begin{tabular}{lcrl}
\hline \multicolumn{1}{c}{ Creek town } & $\begin{array}{c}\text { Approximate } \\
\text { dates occupied }\end{array}$ & $\begin{array}{c}\text { Years } \\
\text { occupied }\end{array}$ & $\begin{array}{c}\text { Physiographic } \\
\text { region }\end{array}$ \\
\hline Apalachicola-Apalachicola Old Town & $1650-1750$ & 100 & Coastal Plain \\
Atasi & $1600-1830$ & 230 & Coastal Plain \\
Coosada & $1775-1830$ & 55 & Coastal Plain \\
Coweta Tallahassee & $1715-1800$ & 85 & Coastal Plain \\
Cusseta-Cusseta Old Town & $1715-1825$ & 110 & Coastal Plain \\
Hoithlewaulee-Fusihatchee-Kalumi- & $1600-1830$ & 230 & Coastal Plain \\
$\quad$ Muklasa area & & & \\
Hickory Ground-Little Tallassee-Little & $1600-1830$ & 230 & Coastal Plain \\
$\quad$ Oakchoy-Coosada Old Town area & & & \\
Tukabatchee & $1600-1830$ & 230 & Coastal Plain \\
Uptaoi & $1790-1825$ & 35 & Coastal Plain \\
Yuchi-Chiaha-Osochi & $1650-1825$ & 175 & Coastal Plain \\
Nuyaka-Okfuskoochee-Tukabatchee & $1775-1830$ & 55 & Piedmont \\
$\quad$ Tallahassee & & & \\
Okfuskee & $1725-1800$ & 75 & Piedmont \\
Pukantallahassee & $1750-1830$ & 80 & Piedmont \\
Wakokai & $1730-1780$ & 50 & Piedmont \\
Abicouche & $1725-1825$ & 100 & Ridge and Valley \\
Coosa Old Town & $1600-1750$ & 150 & Ridge and Valley \\
Natche & $1755-1830$ & 75 & Ridge and Valley \\
Tallasseehatchee & $1770-1830$ & 60 & Ridge and Valley \\
\hline
\end{tabular}

regions (Black et al., in press). The number of catchments within a given physiographic region was relatively small (10 at the most), consequently, the nonparametric Mann-Whitney test was used to determine if there was a significant difference between species associations in the settled versus nonsettled catchments.

The towns included in the catchment analysis were occupied for a wide range of durations (Table I), some for only 35 years and others for around 230 years. This allowed us to segregate out five densely populated village catchments that were occupied for more than 150 years. This separate catchment analysis is limited in its smaller sample size but the impact of the Native Americans on the forest tree distribution should be greater. All five catchments are located in the Coastal Plain physiographic province.

To identify topographic differences between village and control catchments, we determined the proportions of landforms in both catchment types. First, we generated a map of the study area identifying a total of four landforms: north sideslope, south sideslope, hilltop/plateau, and stream valley/floodplain. Landforms were distinguished by analyzing one degree digital elevation models (USGS EROS), the Alabama State Soil Geographic Data Base (STATSGO) digital soil layer (USDA, 1991), and a hydrography layer. The first step was to define stream valleys and flood plains, which we identified as riparian zones with little slope and soils derived largely from 
alluvial deposits. To generate this coverage, streams were buffered using ArcInfo 8.02. Low-order streams (less than 5) were buffered to a width of $40 \mathrm{~m}$ while moderate order streams were buffered to $75 \mathrm{~m}$ and major rivers were buffered to $100 \mathrm{~m}$. Then soils with alluvial parent materials were identified using the STATSGO digital soil layer (USDA, 1991). Alluvial soils were combined with the buffered stream layer, and in some cases the flood plains were slightly extended in major river valleys where slope was less than $1 \%$. Sideslopes were all areas not included in the stream valley/flood plain coverage where slope was greater than $10 \%$. All other areas where slope was less than $10 \%$ and not already classified as stream valley/flood plain were designated hilltop/plateau.

To test the differences between control and village sites, we clipped the landforms map to the catchments with a GIS and tallied the extent of landforms within each catchment. Clipping is a GIS technique of overlaying digital maps to define the union of the two maps. We then conducted Wilcoxon signed ranks tests between the proportions of landforms in the village and control catchments. The nonparametric, Wicoxon signed rank, test was used because of the small sample size of the analysis $(n=10)$. As an additional analysis, we compared the topographic complexity of the two catchment types. To do this, we clipped one-degree digital elevation models (USGS EROS) to the catchment sites and then calculated the mean and standard deviation of elevation for the control and village catchments. The standard deviation of the elevation provides a measure of topographic roughness.

Catchment analyses are advantageous because of the ability to compare randomly selected control samples to the experimental samples. However, this type of analysis operates on only one scale, the scale of the catchment, because catchments are treated as entire units. We were also interested in more fine-scale variation in forest compositional differences. Specifically we wanted to test whether species composition varied as a function of distance from a settlement use area, evaluating Native American influences on a variety of scales. Therefore, as a supplemental method for quantifying the effects of Native American behavior on tree distributions, we performed a distance analysis of witness trees in relation to two isolated, relatively old Native American towns, Coosa Old Town and Tukabatchee (Table I). Coosa Old Town was occupied for about 150 years (1600-1750) (DeJarnett and Hansen, 1960) and Tukabatchee was occupied for over 200 years (ca. 15001800), although not necessarily by the same populations (Knight, 1985). Similar to all other Creek Indian towns, Coosa Old Town and Tukabatchee were situated immediately adjacent to the river, in this case the Coosa River and the Tallapoosa River, respectively. Only two towns were chosen for this analysis because most Creek Indian towns are located along the rivers in 
relatively close proximity to each other. Consequently, towns that are $20 \mathrm{~km}$ away from another town and that had been occupied for a significant number of years (more than 100) are rare.

Procedures involved defining a rectangular corridor of witness trees $2 \mathrm{~km}$ wide and $20 \mathrm{~km}$ long (10 km on each side) around Coosa Old Town and $10 \mathrm{~km}$ upstream (north) of Tukabatchee. We were unable to perform the analysis on the corridor downstream (south) of Tukabatchee because of the presence of another town within $10 \mathrm{~km}$. This corridor was situated along and parallel to the river bottoms in order to control for the effects of elevation and to ensure that any changes in tree distribution were solely the result of the distance from the residential center. We measured the distance to each tree from the town, which was in the center or one end of the corridor. Multinomial logistic regression was used to determine if distance from the town had a significant effect on the species of trees within the corridor and to partition out the effects of the environment (SPSS 10.0). Forest composition was regressed against slope, elevation, direction of slope, and distance to the town.

\section{RESULTS AND DISCUSSION}

A number of statistically significant differences occurred between village and control catchment samples (Table II). These were most pronounced in the Coastal Plain where occupation was heaviest (Table I). There are a number of patterns that are consistent and some that are inconsistent with traditional expectations from the anecdotal evidence from historical sources.

\section{Pine and Building Materials}

Pine is significantly lower in the village catchments versus the control catchments in the Coastal Plain ( $p=0.07$, Table II). Pine is expected to be significantly lower surrounding Native American villages because of depletion for building materials. Eastern, Southwestern, and Northwestern Native Americans used wood for construction materials. The amount of harvested wood can be significant in localized environments. In the eastern United States, specific species used apparently varied but pine was favored for structures when it was available. According to Swanton, an early twentieth-century ethnographer, Chickasaw Indians favored pine but locust and sassafras were sometimes substituted if pine was not available (Swanton, 1979, p. 421). Carolina Indian houses were made of pine while Mississippi 


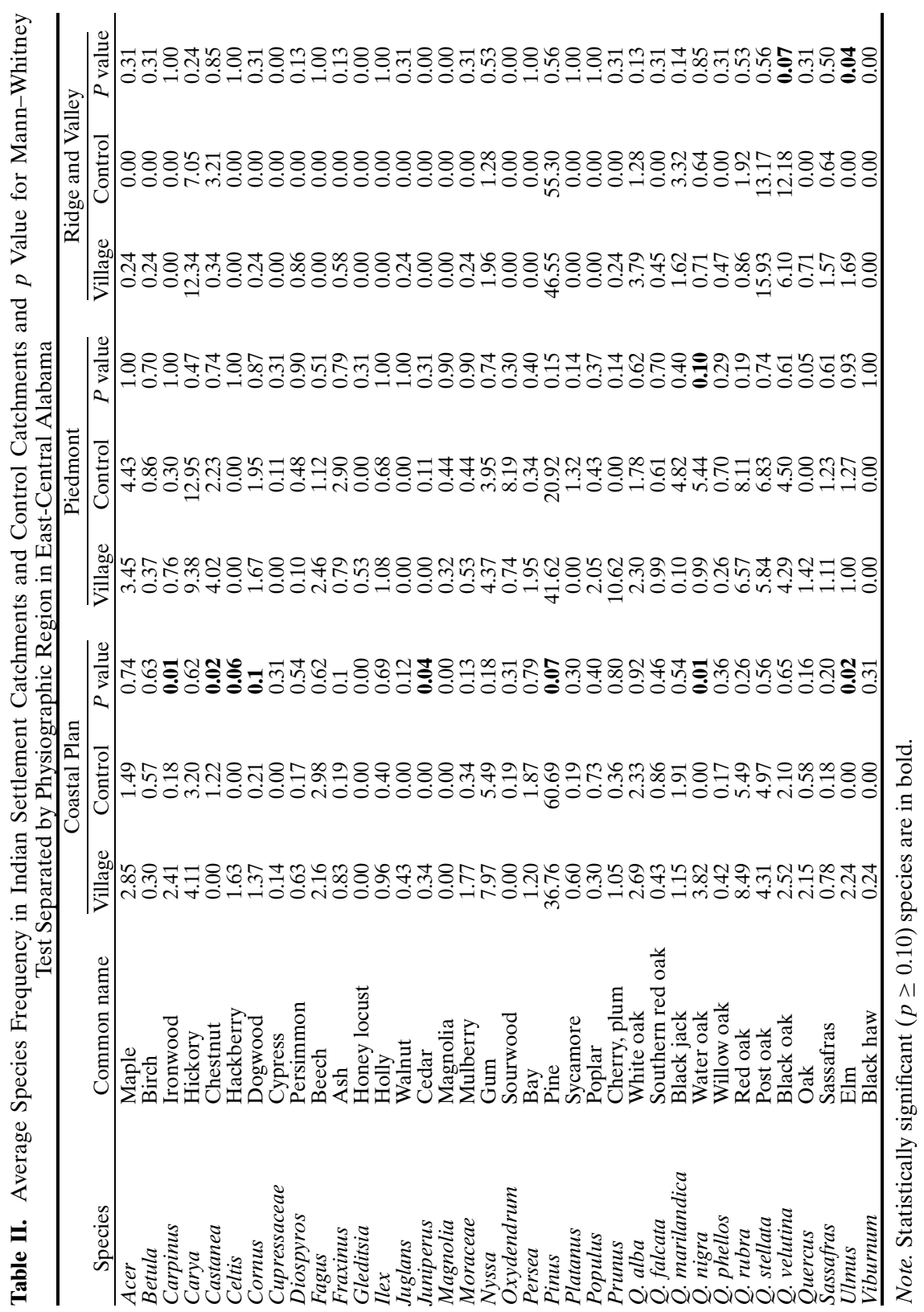


Indians favored any wood that could be easily bent, although hickory, cedar, and pine are mentioned specifically (Swanton, 1979, p. 421). The Seminole Indians of Florida used palmetto.

Palisades and other structures used a significant amount of wood, which was usually pine. Heidenrich (1971, pp. 152-153) concluded that a Huron village of 1000 individuals required 46 acres (15.3 ha) of timber. For the sixteenth-century Coosa chiefdom in northwest Georgia, David Hally has calculated that the King site village used 800 palisade posts of about 0.8 feet $(20 \mathrm{~cm})$ in diameter (Hally, 1988 and personal communication). The King site is culturally, temporally, and geographically similar to the Creek Indians studied in this analysis. The posts at the King site were made of pine. Pine has been documented at other archaeological sites in the deep south as a preferred building material for structures (Polhemus, 1987).

\section{Fruit Trees}

Native American villages were often described by historic travelers as being located in the immediate vicinity of fruit trees (Bartram, 1998). Although the Native Americans were never described as having actively planted fruit trees, they encouraged the growth of particular species that were economically and religiously important. The only tree that southeastern Indians actually planted and transported because it was important for religious and social purposes was the Casine yapon or Ilex vomitoria. This plant is native to the Coastal Plain so its presence in the Piedmont is probably due to transplanting. "[T]he Indians call it the beloved tree, and are very careful to keep them pruned and cultivated" (Bartram, 1998, p. 227). This plant, Ilex vomitoria Ait., was used to make a strong "black drink" that was imbibed daily for purification and social reasons (Hudson, 1976, pp. 226-227). Ilex is not significantly different between the settlement and the control catchments in any of the physiographic regions (Table II). While southeastern Indians may have transplanted and encouraged Ilex, they apparently did not increase the numbers of Ilex immediately surrounding villages.

If Native Americans were encouraging fruit trees surrounding their towns, we would expect a higher frequency of these species (Celtis, Diospyros, Moraceae, and Prunus) in the village catchments. Hackberry is the only fruit species that is significantly more frequent in the villages relative to the control catchments (Table II). Although Indians were observed to have "groves" of fruit trees (Bartram, 1998, p. 59), these trees were not significantly close to villages. 


\section{Agricultural Techniques}

Most witness tree studies of the effects of Native Americans on forest species have emphasized forest fires (Delcourt, 1976; Kusmer et al., 1987). These studies suggested that Native Americans' use of fire in agriculture and hunting may have shifted the forest distribution toward fire tolerant species. Agriculture was more prevalent in the southeast United States but has been practiced in varying degrees all over North America for hundreds of years.

Most North American Indians practiced small-scale horticulture. Small fields were cleared and worked by members of individual towns. In the southeast these fields were located immediately adjacent to towns in the river bottoms from the beginning of the Mississippian period (A.D. 1000) to Indian removal (A.D. 1836). There is evidence, however, that some southeastern Indians in the late historic period (post A.D. 1800) were abandoning river bottom settlements and "settling out" into the uplands for a variety of reasons (Waselkov, 1997).

Techniques for field preparation were relatively consistent throughout the eastern United States. Virgin forests were rarely cleared for agricultural land. Instead, large trees were girdled and left to fall in the winter storms (Adair, 1930; Silver, 1990). The understory was cleared by burning (Ethridge, 1996, p. 229). Old fields were reused before new ones were cleared because of the labor involved. Approximately 100 ha were cleared for an average late historic southeastern Indian town.

Native American agricultural practices and timbering for structural materials in this region would be expected to have produced a greater frequency of early succession species immediately surrounding villages. William Bartram, a well-cited eighteenth-century botanist and explorer of the southeast, observed " . ... in the antient cultivated fields, 1. Diospyros, 2. Gleditsia triacanthos, 3. Prunus Chicasaw, 4. Callicarpa, 5. Morus rubra, 6. Juglans exaltata, 7. Juglans nigra ..." (Bartram, 1998, pp. 24-25). While these trees were mentioned by late eighteenth-century travelers as being more frequent in agricultural fields, none were significantly more frequent in the village versus the control catchments. However, cedar, a classic early succession species, is more frequent surrounding Coastal Plain settlements relative to the control catchments (Table II).

In all, the early succession species are inconclusive with respect to the expectations of a Native American altered forest landscape surrounding towns. If southeastern Native American agricultural practices did encourage disturbed environment tree species, the difference was not very significant. 


\section{Nut Trees}

Nuts were a major subsistence resource and were encouraged by North American Indians. Hickory nuts were the most utilized and collected. Coweta Tallahassee, a Creek town on the Chattahoochee River in Alabama, was located near a 2000-acre stand of hickory and oak trees just west of the town (Hawkins, in Ethridge, 1996, p. 217). Native Americans used live oak acorns to make oil for seasoning and for roasting (Bartram, 1998, p. 55). William Bartram observed in the late eighteenth century, “... and the fruit is in great estimation with the present generation of Indians, particularly Juglans exalta commonly called shell-barked hickory; the Creeks store up the latter in their towns. I have seen above an hundred bushels of these nuts belonging to one family" (Bartram, 1998, pp. 24-25).

Native Americans were never described as actively planting these nut trees, but the fact that they foraged and stored the nuts of specific oaks and hickory trees near villages would lead us to expect a higher frequency of these species in the immediate vicinity of their settlements. Similarly, the Indians may have encouraged food-producing trees by simply not cutting them down. Nevertheless, hickory species are not statistically different in any of the catchment analyses (Table II). It will be shown below that there is an increased frequency of hickory beyond the $2-\mathrm{km}$ catchment, however.

\section{Topographic and Elevation Analysis}

To determine if the variation observed above was due to edaphic conditions, we compared the proportion of topographic landforms in the control catchments to the proportion of topographic landforms in the village catchments. These results are illustrated in Fig. 2. A Wilcoxon signed ranks test revealed that there is a significant difference between the proportion of north facing sideslopes and the proportion of south facing sideslopes between village and control catchments ( $p=0.013$ and 0.009 , respectively). This analysis revealed that there is no significant difference between the proportion of hills and the proportion of stream valleys between village and control catchments, however ( $p=0.959$ and 0.285 , respectively). This indicates that there is no difference in the proportion of alluvial deposits and riparian zones between the village and control catchments but that the aspect of slopes greater than $10 \%$ is different between the control and village catchments. There may be a slight avoidance by beech, bay, white oak, ironwood, and holly for south slopes and a preference for north slopes by water oak (Black et al., in press). Ironwood is significantly more frequent in the village catchments in the Coastal Plain $(2.41 \%$ versus $0.18 \%, p=0.01$, Table II), 


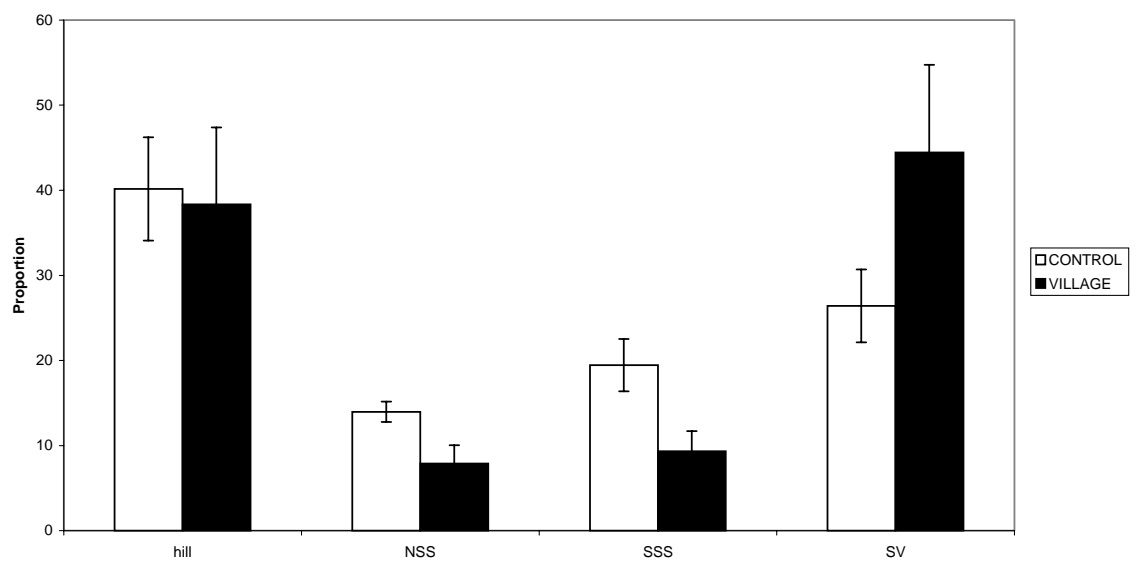

Fig. 2. Bar graph of proportion of landforms in the control and settlement catchments in central Alabama (Hills, NSS: north side slopes, SSS: south side slopes, and SV: stream valley).

which may indicate that the Coastal Plain village catchments contribute to the higher frequency of north sideslope landforms in the landform analysis above.

Another measure of topographic variation is the total mean and standard deviation of the elevation of each catchment group. The mean and standard deviation of the elevation in village catchments were 55.6 and $14.2 \mathrm{~m}$, respectively. The mean and standard deviation of the elevation in control catchments were 89.0 and $31.2 \mathrm{~m}$, respectively $(t=8.3, p<0.05)$. The control catchments have a higher variation in elevation indicating that there is more topographic roughness in the control catchments. This is consistent with the landform analysis, which indicated that the percentage of northfacing and south-facing sideslopes differs between the control and village catchments. The greater topographic roughness and higher elevation among the control catchments may explain some of the mesophytic species (ironwood, ash, dogwood, sycamore, and water oak) variation between the village and the control catchments.

\section{Distance Analysis}

Catchment analyses are limited in that they only characterize a relatively small area surrounding a point and treat it as a single unit. To better quantify the effects of Native Americans on the forest tree frequencies, we performed a distance analysis along a corridor $10 \mathrm{~km}$ on each side of two 
Native American towns along the river. With this type of analysis we are able to quantify the gradual changes over space of Native American behaviors on the distribution of specific trees. Distance was measured along the river bottom so that environmental variables could be controlled and any change in tree frequencies would be solely a function of the distance from the towns. Coosa Old Town and Tukabatchee were chosen for this analysis because of their relative isolation. Coosa Old Town is located in the Ridge and Valley and Tukabatchee is located in the Coastal Plain.

Multinomial logistic regression was used to quantify the influence of distance from Creek towns on the distribution of tree species. The significance value of the likelihood ratio test measures the significance of each independent variable in predicting the dependent variable, species of tree, in the Coosa Old Town and Tukabatchee corridor witness tree sample. Distance is significant for predicting the forest distribution around Creek Indian towns $(p=0.09)$. These results indicate that mere distance from a town is a significant variable in predicting tree species in the study region. In other words, the presence of an Indian town is a significant predictor of tree species and forest composition.

In the application to Creek Indian village settlements, however, this technique is limited in its statistical power and replicability because Native American settlement in the study region was relatively dense. Towns were situated along rivers and were relatively close together, sometimes immediately adjoining one another and usually within a few kilometers. This is not limited to the southeast but is common among sedentary horticultural societies of North America. Consequently, it is difficult to locate a town that was relatively isolated and that allows a distance analysis such as this. Human interaction studies must be able to quantify human settlement over space and time within a reasonable range of error.

Pine increases and is relatively consistent in frequency beyond $2000 \mathrm{~m}$ at both Coosa Old Town and Tukabatchee (Figs. 3 and 4). This is consistent with the expectations above regarding Native American use of pine for building. This is also consistent with our finding that pine is less frequent in village catchments relative to the control catchments.

Hickory shows the opposite result. Hickory is much higher in frequency immediately surrounding the two Indian towns, particularly Tukabatchee (Figs. 3 and 4). As mentioned above, hickory nuts were a major staple among eastern North American Indians. While Native Americans do not appear to have cultivated the trees, they collected and stored hickory nuts. This central foraging technique may have resulted in an increased frequency of hickory near Native American towns. However, there is no apparent pattern for oak.

Field and fruit species are expected to have a higher frequency close to the towns. These tree species are more frequent up to $6000 \mathrm{~m}$ away 


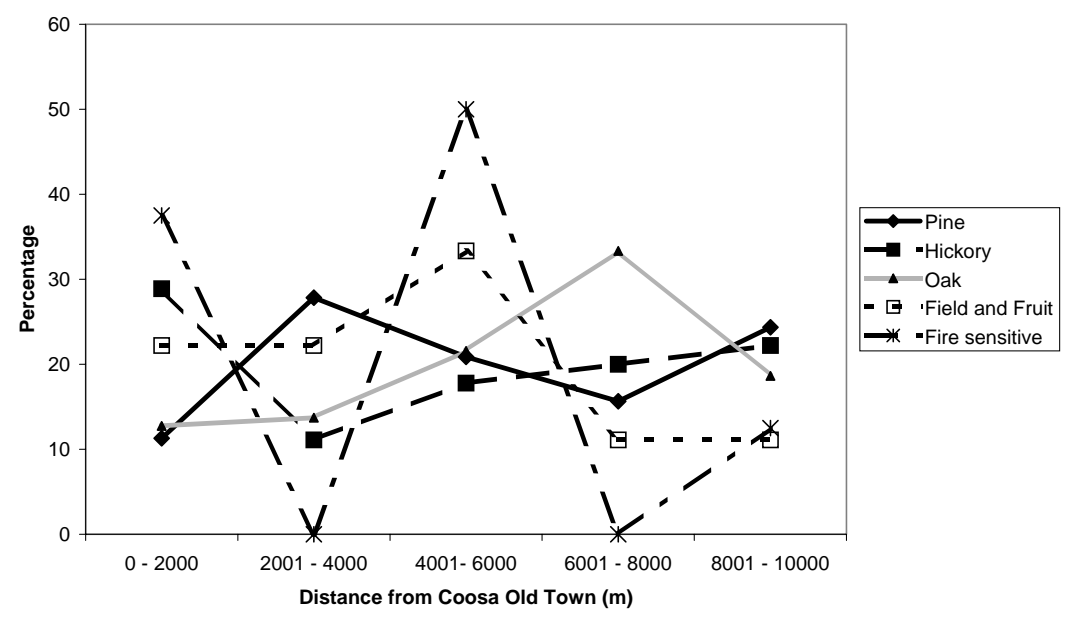

Fig. 3. Line graph of average species percentage by distance (m) away from Coosa Old Town in central Alabama.

from the Coosa Old Town and are more frequent within the first $4000 \mathrm{~m}$ of Tukabatchee (Figs. 3 and 4).

Fire sensitive species are difficult to interpret. These species are expected to be lower in frequency near towns due to burning related to

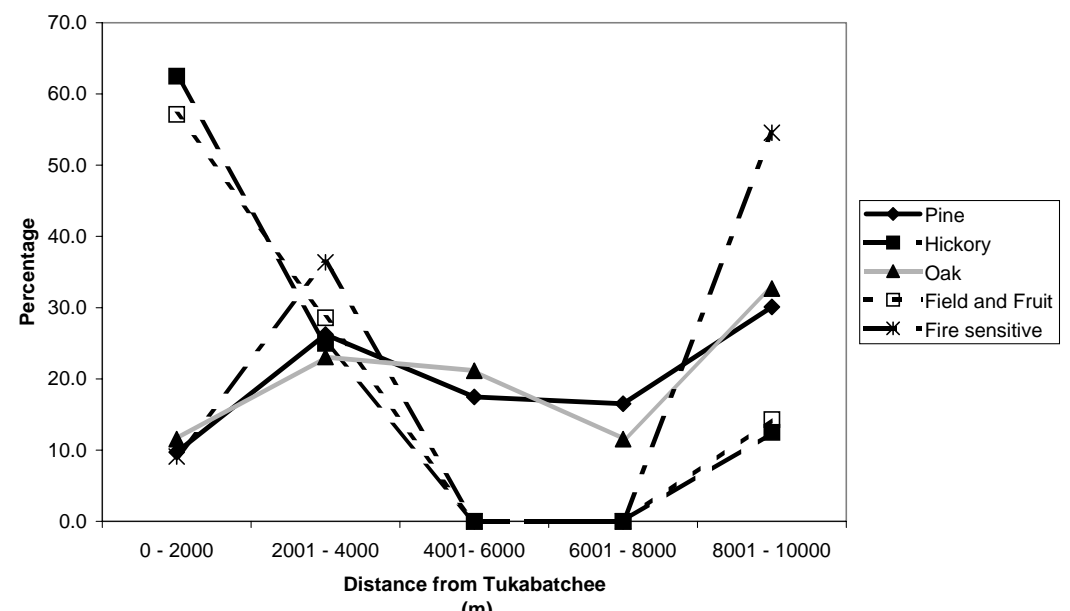

(m)

Fig. 4. Line graph of average species percentage by distance $(\mathrm{m})$ away from Tukabatchee in central Alabama. 
agricultural practices. At Coosa Old Town and Tukabatchee, these species appear to be distributed in a spatially cyclical pattern. The patterns for these two villages are not exactly the same but are very similar. In general, they are relatively high for the first $2000-4000 \mathrm{~m}$, then drop off to zero percentage around $4000 \mathrm{~m}$. Then they rebound again in frequency. There appears to be a spatially cyclical pattern of frequency that may be related to the distribution of agricultural fields along the river bottom corridor (Waselkov, 1997).

\section{CONCLUSION}

This paper has summarized the largest sample of witness trees in a Native American-forest interaction study to date. Thirty Creek Indian towns comprising 18 settlement catchment areas which spanned almost 300 years of occupation were analyzed with witness tree catchment analysis and distance analysis. Previous witness tree catchment studies of Indian settlement on the structure of forests have been in the northeastern and midwest United States and have found clear differences between Indian settlement catchments and non-Indian settlement control catchments. Overall, the catchment analyses do not show drastic changes between the village settlement catchments and the nonsettled control catchments. Recent studies similar to this have demonstrated a clear difference between Indian settlement regions and nonIndian settlement regions (Black and Abrams, 2001; Ruffner, 1999; Wycoff, 1991). The results in this study are from a much larger data set and cover a larger sample region. Nevertheless, the effects of Indian habitation seem to be less than in the northeast United States. This may be due to the greater frequency of forest fire in the southeast relative to the northeast where most previous catchment studies have occurred. Native American influences are probably less in the greater disturbed forests of the southeast. In locations of longer and more intensive occupation, such as the Coastal Plain, the differences between settlement and control catchment tree frequencies were greatest. Pine shows a significant decrease around villages. Early succession species such as cedar and elm are more frequent because of the greater disturbance from agricultural practices and human habitation.

Lower frequencies of Pinus spp. were observed around villages of the Coastal Plain and Ridge and Valley. Pinus spp. was used by Native Americans in this region as building material for structures and palisades. Early succession species were more frequent in village catchments relative to control catchments in the Coastal Plain where Native American settlement was more dense.

Distance analysis was performed on two towns. This analysis supplements the catchment analysis by quantifying gradual changes in the tree 
frequency distribution over space. Pinus increases in frequency beyond $2000 \mathrm{~m}$ away from villages. Carya shows the opposite result. This species is higher in frequency within the first $2000 \mathrm{~m}$ closest to villages. Field and fruit species were more frequent up to $6000 \mathrm{~m}$ away from villages and then dropped off in frequency. Fire sensitive tree species appear to be in a pattern which repeats itself or cycles over space with increasing and decreasing frequency as a function of distance from villages. This spatially cyclical pattern may be related to the placement of Native American villages along the river bottom.

Previous studies of pre-European forests have stated that Native Americans may have influenced the distribution of specific trees but have not attempted to measure the degree of such changes. This study demonstrated that Native Americans might have altered a wide range of species in addition to the often-cited forest fire effect. Humans are not simply recipients of forest resources but have been actively altering the distribution of tree species. Any studies of diet, foraging, and resource use over time and space must be able to characterize the effects that humans have had on those resources.

\section{ACKNOWLEDGMENTS}

Funding for this project was provided to Foster by the Hill Fellowship, Department of Anthropology, Pennsylvania State University, and a contract from the Conservation Program of the Strategic Environmental Research and Development Program (SERDP) with Oak Ridge National Laboratory (ORNL). ORNL is managed by UT-Battelle, LLC, for the U.S. Department of Energy under contract DE-AC05-00OR22725. The authors thank David J. Hally for sharing data on the King site and for the very useful and thorough comments of three anonymous reviewers.

\section{REFERENCES}

Abrams, M. D., and Ruffner, C. M. (1995). Physiographic analysis of witness tree distribution (1765-1798) and present forest cover through north-central Pennsylvania. Canadian Journal of Forest Research 25: 659-668.

Adair, J. (1930). Adair's History of the American Indians, Watauga Press, Johnson City, TN. Reprint edited by Samuel Cole Williams.

Bartram, W. (1998). In Harper, F. (ed.), The Travels of William Bartram, University of Georgia Press, Athens.

Black, B. A., and Abrams, M. D. (2001). Influences of physiography, surveyor bias, and Native American catchments on witness tree distribution in southeastern Pennsylvania. Ecology 82: $2574-2586$. 
Black, B. A., Foster, H. T., and Abrams, M. (in press). Combining environmentally dependent and independent analysis of witness tree data in east-central Alabama. Canadian Journal of Forest Research 32: 2060-2075.

Bourdo, E. A., Jr. (1956). A review of the General Land Office Survey and of its use in quantitative studies of former forests. Ecology 37: 754-768.

Braun, E. L. (1950). Deciduous Forests of Eastern North America, Free Press, New York.

Burgess, L. H., Wilson, C. S., McBride, E. H., Anderson, J. L., and Dahms, K. E. (1960). Soil survey of Montgomery County, Alabama. U.S. Department of Agriculture, Soil Conservation Service, Washington, DC.

Clark, J. S., and Royall, P. D. (1995). Transformation of a northern hardwood forest by aboriginal (Iroquois) fire: Charcoal evidence from Crawford Lake, Ontario, Canada. The Holocene 5(1): $1-9$.

Davies, K. M., Jr. (1994). Some ecological aspects of northeastern American Indian agroforestry practices. Northern Nut Growers Association, Annual Report 85: 25-37.

Day, G. M. (1953). The Indian as an ecological factor in the northeastern forest. Ecology 34(2): 329-346.

DeJarnett, D. L., and Hansen, A. T. (1960). The Archeology of the Childersburg Site, Alabama. Notes in Anthropology. The Department of Anthropology, Florida State University, Tallahassee.

Delcourt, H. R. (1976). Presettlement vegetation of the north of Red river Land District, Louisiana. Castanea 41: 122-139.

Delcourt, H. R., and Delcourt, P. A. (1974). Primeval magnolia-holly-beech climax in Louisiana. Ecology 55: 638-144.

Delcourt, P. A., Delcourt, H. R., Ison, C. R., Sharp, W. E., and Gremillion, K. J. (1998). Prehistoric human use of fire, the Eastern Agricultural Complex, and Appalachian oak-chestnut forests: Paleoecology of Cliff Palace Pond, Kentucky. American Antiquity 63: 263-278.

Dorney, C. R., and Dorney, J. R. (1989). An unusual oak savanna in northeastern Wisconsin: The effect of Indian-caused fire. American Midland Naturalist 122(1): 103-113.

Dorney, J. R. (1981). The impact of Native Americans on presettlement vegetation in southeastern Wisconsin. Wisconsin Academy of Sciences, Arts and Letters 69: 26-36.

Early, A. M. (2000). (ed.) Forest farmsteads: A millennium of occupation at Winding Stair in the Ouachita Mountains. Arkansas Archaeological Research Series 57. Arkansas Archaeological Survey, Fayettteville.

Ethridge, R. F. (1996). A Contest for Land: The Creek Indians on the Southern Frontier, 17961816, PhD Dissertation, University of Georgia, Athens.

Fenneman, N. M. (1938). Physiography of the Eastern United States. McGraw-Hill, New York.

Foster, H. T., II. (2001). Long-Term Average Rate Maximization of Creek Indian Residential Mobility: A Test of the Marginal Value Theorem, PhD Dissertation, The Pennsylvania State University, University Park.

Godfrey, R. K.(1988). Trees, Shrubs, and Woody Vines of Northern Florida and Adjacent Georgia and Alabama, University of Georgia Press, Athens.

Hally, D. J. (1988). Archaeology and settlement plan of the King Site. In Blakely, R. L. (ed.), The King Site: Continuity and Contact in Sixteenth Century Georgia, University of Georgia Press, Athens, pp. 3-16.

Heidenreich, C. (1971). Huronia: A History and Geography of the Huron Indians, 1600-1650. McClelland and Stewart, Toronto.

Hudson, C. (1976). The Southeastern Indians. University of Tennessee Press, Knoxville.

Knight, V. J., Jr. (1985). Tukabatchee: Archaeological investigations at an historic Creek town, Elmore Couny Alabama, 1984, Report of Investigations 45, University of Alabama, Alabama State Museum of Natural History, Office of Archaeological Research.

Kusmer, K. D., Leach, E. K., and Jackson, M. J. (1987). Reconstruction of precolonial vegetation in Livingston County, Kentucky and prehistoric cultural implications. Southeastern Archaeology 6: 107-115.

Lafitau, J. (1724). Moeurs des sauvages Americains compares aux moeurs de premiers temps. Saugrain, Paris. 
Lutz, H. J. (1930). Original forest composition in northwestern Pennsylvania as indicated by early land survey notes. Journal of Forestry 28: 1098-1103.

Milfort, L. L. (1972). Memoirs or a Quick Glance at My Various Travels and My Sojourn in the Creek Nation, Beehive Press, Savannah, GA.

Milner, G. (1998). The Cahokia Chiefdom: The Archaeology of a Mississippian Society. Smithsonian Institution Press, Washington, DC.

Munson, P. J. (1986). Hickory silviculture: A subsistence revolution in the prehistory of eastern North America. Paper presented at the Conference on Emergent Horticultural Economies of the Eastern Woodlands, Southern Illinois University, Carbondale, March 28-29.

Polhemus, R. (1987). The Toqua site: A late Mississippian, Dallas phase town, Report of Investigations, No. 41, Department of Anthropology, University of Tennessee.

Pyne, S. J. (1983). Indian fires. Natural History 2: 6-11.

Ruffner, C. M.(1999). A Regional and Catchment Analysis of Native American Influences on PreEuropean Settlement Forests of the Allegheny Plateau, PhD Dissertation, The Pennsylvania State University, University Park.

Sabo, G., Lockhart, J. J., and Hilliard, J. E. (2002). The forest as a resource: From prehistory to history in the Arkansas Ozarks. Paper presented at the Upland Oak Ecology: History, Current Conditions, and Sustainability Symposium, Fayetteville, AR, October 7-10, 2002.

Sagard, G. (1968). In Wrong, G. M. (ed.), The Long Journey to the Country of the Hurons, Greenwood Press, New York.

Schroeder, S. (1997). Place, Productivity, and Politics: The Evolution of Cultural Complexity in the Cahokia Area, PhD Dissertation, Pennsylvania State University.

Silver, T. (1990). A New Face on the Countryside: Indians, Colonists, and Slaves in South Atlantic Forests, 1500-1800. Cambridge University Press, Cambridge, UK.

Swanton, J. R. (1922). Early history of the Creek Indians and their neighbors, Bureau of American Ethnology, Bulletin 73, Smithsonian Institution, Washington DC.

Swanton, J. R. (1979). The Indians of the Southeastern United States. Classics of Smithsonian Anthropology, Smithsonian Institution Press, Washington DC.

USDA - NRCS (1991). State Soil Geographic (STATSGO) Data Base: Data use information, United States Department of Agriculture, Natural Resources Conservation Service, Miscellaneous Publication No. 1492, Washington, DC.

Vita-Finzi, C., and Higgs, E. S. (1970). Prehistoric economy of the Mount Caramel area of Palestine: Site catchment analysis. Proceedings of the Prehistoric Society 36: 1-37.

Waggoner, G. (1975). Eastern deciduous forest, Vol. 1: Southeastern Evergreen and Oak-Pine region, Natural History Theme Studies, No. 1, National Park Service.

Waselkov, G. A. (1997). Changing strategies of Indian field location the early Historic Southeast. In Gremillion, K. J. (ed.), People, Plants, and Landscapes: Studies in Paleoethnobotany, University of Alabama Press, Tuscaloosa, pp. 179-194.

Waselkov, G. A., and Holland Braund, K. E. (1995). William Bartram on the Southeastern Indians, University of Nebraska Press, Nebraska.

Waselkov, G. A., and Smith, A. (2000). Upper Creek archaeology. In McEwan, B. G. (ed.), The Indians of the Greater Southeast: Historical Archaeology and Ethnohistory, University Press of Florida, Gainesville, pp. 242-264.

Worth, J. (2000). The Lower Creeks: Origins and early history. In McEwan, B. G. (ed.), The Indians of the Greater Southeast: Historical Archaeology and Ethnohistory, University Press of Florida, Gainesville, pp. 265-298.

Wycoff, M. W. (1991). Black walnut on Iroquoian landscapes. Northeastern Indian Quarterly 8: $4-12$. 